\title{
Russia and the Ukrainian Crisis: A Multiperspective Analysis of Russian Behaviour, by Taking into Account NATO's and the EU's Enlargement
}

Maximilian Klotz

\section{Abstract}

This article will explain why Russia annexed Crimea and is destabilizing eastern Ukraine. To do this, three different theoretical approaches on various levels of analysis will be used. It will be examined how far the expansion of NATO, as well as that of the European Union (Theory of Neorealism), was a motive for Russia's action. NATO's enlargement is analysed predominantly. In addition, politicalpsychological motivations of the Russian leadership are considered. But it is also analysed whether Russia's pure power interests have played a role (Theory of Realism). The focus here is on the Russian naval base in Crimea. It is necessary to examine whether preserving its fleet in the Black Sea was a motive for Moscow to annex the Crimean peninsula.

KEY WORDS:

Ukrainian crisis, Russia, NATO, EU, annexation of Crimea 


\section{Introduction and current state of research}

"Unilateral and frequently illegitimate actions have not resolved any problems. [...] [T] hey have caused new human tragedies and created new centers of tension" (Putin 2007). The Russian course of action in eastern Ukraine and in the Crimean peninsula, since spring 2014, seems to comply with this "unilateral," "illegitimate" manner (Engelberg 2016: 61; McFaul 2014: 170), whereby Vladimir Putin, back in 2007, criticized the "unipolar" US world order as "not only unacceptable but also impossible in today's world" (Putin 2007; Ehlers 2014: 26).

This article tries to explain Russian behaviour in the course of the Ukrainian crisis. Russia transformed "eastern Ukraine into a permanent trouble spot" (Portnov 2014: 8) - the area around "Donezk and Luhansk" (Ehrhart 2014: 28) - as well as previously annexing the "Crimean peninsula in the Black Sea" (Portnov 2014: 6).' Thus it was Russia that "unleashed" the Ukrainian crisis (Maćków 2015: 11, 17). However: Why did Russia annex Crimea and why is it still destabilizing eastern Ukraine? This research question guides this article and has to be answered. Answering the question seems to be relevant for clarifying whether further steps of this kind have to be expected from Russia (Treisman 2016: 47). Because the Russian state "is usually equated with the president" (Maćków 2015: 63), I use (among others) speeches made by Russian President Putin, before and within the Ukrainian crisis, as primary sources.

The research literature has already pointed out possible explanations for Russia's behaviour: Jerzy Maćków (2015: 18) understands the Ukrainian crisis "as a permanent conflict of European cultural and political worlds," which became "acute in 2014," though the conflict has "become historical". For John J. Mearsheimer ${ }^{2}$ the Ukrainian crisis is thus far - especially in the opinion of the West - a result of the aggressive Russian behaviour (Mearsheimer 2014: 77). However, this is a miscalculation, because he has the following thesis: "[T]he United States and its European allies share most of the responsibility for the crisis" (ibid.). More precisely, three developments are

1 An end to this destabilization by Russia, even within 2017, and beyond, is not to be expected (Beddoes 2016: 13). 
relevant: NATO expansion, as the "taproot of the trouble," the expansion of the European Union in eastern Europe, and "the West's backing of the pro-democracy movement in Ukraine" (ibid.). By annexing Crimea, Putin did not implement a long-planned strategy, argues Mearsheimer, but rather it was "a spontaneous reaction to Yanukovich's ousting" (ibid.: 85). Likewise, Daniel Treisman has doubts about a long-time-planned strategy of Putin, which illustrates "the chaotic manner" of Russia's course of action in Crimea (Treisman 2016: 48). Treisman traces Russian behavior in the Ukraine to two other possibilities: the imperialistic ambitions of Putin within the post-Soviet area and "a hastily conceived response to the unforeseen fall of [...] Yanukovich" (ibid.: 2016: 47). The Russian action in Crimea also depends on its Black Sea fleet in Sevastopol, which has great significance for Russia (ibid.: 50). Vittorio Hösle does not interpret Russia's action "as a spontaneous reaction," because Hösle assumes that "schemes for annexation of Ukrainian territory" have already existed "for a long time" (Hösle 2015: 106). Hösle emphasizes domestic challenges, which forced Putin to achieve "foreign policy successes" (ibid.: 107).

Michael McFaul also looks at the difficulties into which the Putin regime got in its own country, and therewith can the Russian action be explained (McFaul 2014: 169). Similarly, Stefan Meister reads the "legitimacy deficit of the Putin system" as the "main reason" for the intensifying "conflict between Russia and the West" (Meister 2015: 2). According to Wolfgang Zellner, the Ukrainian Maidan and the protests in Russia are a threat to "Putin's system of rule" (Zellner 2015: 91). Analyzing Russia's new military doctrine, Margarete Klein analogically recognizes the worry about a "Maidan 'scenario" existing in Russia (Klein 2015a: 4). Klaus von Beyme notices a transformation of the Russian "security concept [...], from being based on NATO, to a rejection of Western institutions" (Beyme 2016: 43). Nadia Alexandrova-Arbatova calls the Ukrainian crisis "the first direct conflict between the differing regional strategies of Russia and the EU" (Alexandrova-Arbatova 2017: 13). Ukrainian membership of the EU, and NATO, seems to be unlikely (Ehrhart 2014: 30). Nevertheless, there has already been a "rapprochement" of Ukraine to these Western institutions, which still continues to move forward (ibid.).

The data basis for this work is profound. As the previously mentioned state of research suggests, the approach for the leading question could be quite 
revealing if theoretical approaches on different levels of analysis are used. ${ }^{3}$ That is why Russia's behaviour will be analysed from multiple perspectives in section four, by using the following three theoretical approaches. First, the theory of realism by Hans Joachim Morgenthau (Morgenthau 1963), which focuses on the state as the prime level of analysis. Second, the theory of structural realism (also called neorealism) by Kenneth Waltz (Waltz 1979), looking at a systemic level of analysis, namely international politics. And third, a political-psychological theory will be used, written by Stavros Mentzos (Mentzos 1995), which concentrates on a humanpsychological dimension. The hypotheses, which are deduced from these three theories, will be verified in the empirical part of this work. In testing the hypotheses in the analytical part, the focus will be mainly on NATO's expansion (Section 4.2.1.) as a possible explanation for Russian behaviour. Finally, the results of the analysis will be listed in the conclusion. But first of all, the issue must be described by collecting the most important facts.

\section{Basic description of the issue}

Since the end of Cold War, the US has been a military hegemon (Müller 2015: 309; Menzel 2016: 37; Nye 2017: 16). ${ }^{4}$ NATO has spread to the former Soviet sphere of influence and borders the Russian Federation (Giegerich 2012: 45-46). NATO's missile defence system, agreed upon in 2010 at the Lisbon summit and predominantly financed by the USA, has been "provisionally" ready for action since 2016 and will be completed in 2018 (Dickow et al. 2016: 1-2; NATO 2016a). Likewise, the European Union, simultaneously, accommodated new members from Eastern Europe (Wessels 2009: 960). In 2003, the European Neighbourhood Policy was established by the EU (Lippert 2014: 2), which Ukraine joined and "received the status of a neighboring state without membership prospects" (Bos 2010: 574; Maćków 2015: 108-110). Thus the West, used here in the sense of NATO and the EU states, is superior to Russia both in military and economic terms. Accordingly an imbalance of power can

3 Cf. Kenneth Waltz's three analytical levels (Krell 2009: 156); compare this also with the following statements. 
In 2010, Russian President Medvedev and the President of Ukraine Yanukovich signed a contract about maintaining the Russian Black Sea fleet on Ukrainian territory for a further 25 years, with an option for a further 5 years, provided "neither party chooses to terminate the agreement" (Kremlin 2010; Cross 2017: 45). In 2011 and 2012, a domestic crisis became manifest in Russia (Schröder 2012: 27-28). To the end of Medvedev's term his approval rates declined ${ }^{6}$ and discontent in the population increased (ibid.: 27). Hence "the political elite manipulated in a number of the regions" the results of the Duma elections (ibid.). ${ }^{7}$ These "evident manipulations" led to "mass demonstrations" in the Russian capital and other cities (ibid.). Putin himself achieved in the following presidential elections (just) 63.6 percent $^{8}$ (ibid.). At Putin's inauguration there were, once more, (some huge) demonstrations (ibid.).

The immediate causes of the Ukraine crisis were "developments" in Ukraine itself (Maćków 2015: 11, 17): From the end of 2013 to the beginning of 2014, the Ukrainian population partly protested in the Ukrainian capital "and at other places in the country [...], against the [...] regime of President Viktor Yanukovich and for an association agreement with" the EU (Maćków 2015: 16-17; Quiring 2014: 14). Previously, the Ukrainian government chose "not to sign" the agreement with the EU (Göler 2015: 300; Maćków 2015: 86); 9 before this, Russia put "massive pressure" on the Ukrainian governance (Göler 2015: 300; Maćków 2015: 86). The protests, also called "Euromajdan," evolved into a "national movement" (Maćków 2015: 87). The use of force against the demonstrators culminated in "shooting" them (20-21 February); ${ }^{10}$ shortly afterwards the pro-Russian President Yanukovich fled ("unexpectedly") "to Russia" (ibid.: 88-89). According

5 In 2011, the GDP of the EU states (in million US dollars) was nearly ten times that of Russia's; there is a similar factor by comparing the military expenditures (in billion US dollars); GDP p.c. in Russia ranks at 10.119 US dollars, while that of the US is at 59.391 US dollars; the EU has about 3.5 times as many inhabitants as Russia (Weidenfeld 2015: 205; The Economist 2016:96,99). Of course it is not the intention to create the impression that Europe and the US do not have weak points themselves (Niblett 2017: 19-21; 24).

6 Even Putin's approval rates declined.

7 In 2012, the election results for the United Russia party were about 49.3 percent, yet in 2007 the party won 64.3 percent (Schröder 2012: 27).

8 In 2004, Putin reached 75.03 percent; in 2008, Medvedev obtained 70.28 percent (Schröder 2012: 27).

9 Until then the Ukrainian government tried, even while Yanukovich was president, "to work towards the agreement" (Göler 2015: 299). When the new government came to power, the agreement was signed on 27 June 2014 (Ehrhart 2014: 30).

10 Within two days, 98 people were killed (Maćków 2015: 88). 
to Russian President Putin, this overthrow of Yanukovich was a "coup" (Putin 2014a). Russia moved on to a so-called "hybrid warfare," where "military means" are combined with "nonmilitary ones" (Klein 2015b: 48). For this, Moscow used "regular Russian troops, which, however, acted as disguised 'separatists" (Maćków 2015: 11). "Separatist movements" in eastern Ukraine were supported by Russia (Maćków 2015: 90-91; Portnov 2014: 6). There, "the political conflict" evolved "into a war" (Portnov 2014: 6; Maćków 2015: 11, 90-91). The annexation of Crimea to Russian territory succeeded only through the use of Russian soldiers (Maćków 2015: 90). In March 2014, "a referendum on Crimea" was held, "whereby the residents of the peninsula [...] [would have] expressed their wish" - "more than 96\%" - "to unite with Russia" (Putin 2014b; Putin 2014a). On 18 March 2014, "Crimea and Sevastopol" were integrated "into the Russian Federation" (Eitelhuber 2015: 310). Officially Putin justified Russia's behaviour by referring to history. Thus the "spiritual origins" of the Russian nation would come from Crimea (Putin 2014b).

\section{Theoretical approach}

\section{Macht und Frieden. Grundlegung einer Theorie der internationalen Politik (Power and peace. Foundation of an international politics theory)}

\section{- Realism by Hans J. Morgenthau: theoretical foundations}

The fundamental assumption of Hans J. Morgenthau's theory is that politicians "think and act [...] in terms of power, understood as interest" (Morgenthau 1963: 51). A politician has to analyse "what is possible in the concrete circumstances of time and place" and favourable "for the national power" (ibid.: 52, 73). Insofar as politics in the international system is "a struggle for power," its "immediate aim is constantly power" (ibid.: 69, 74-77). The "military strength" of a state is "the most important material factor [...] [of its] political power" (ibid.: 71). Further "elements of coincidence" also affect the foreign policy of a state (ibid.: 53). Politics is about maintenance of power, an increase of power or a demonstration 
of power; at the international level, this results in "three typical forms of international politics": a "policy of status quo," an imperialistic policy or a policy of prestige (ibid.: 81).

\section{Operationalization and derivation of the hypotheses}

Now, hypotheses must be deduced from these theoretical basics. The hypotheses will be tested in the analytical part of this paper. Realism ascribes the foreign policy behaviour of a state (dependent variable) to its "interest understood in the sense of power" (independent variable). The current state of research already refers to a potential strategic importance of its naval base in the Black Sea to Russia (Treisman 2016: 50; Cross 2017: 44-46). By annexing Crimea, and with it also the port city of Sevastopol, Russia could follow an (international) "policy of status quo". With the escape of the pro-Russian President Yanukovich, an "element of coincidence," Russia could have feared a loss of its military base: To maintain its military power, Russia ought to have tried to preserve its naval base in Crimea (independent variable). This is on the assumption that the base is of particular strategic importance for Russia. With the overthrow of Yanukovich (intervening variable), Russia could have feared a termination of the contract for the continuity of the Russian naval base in Ukrainian territory (intervening variable), which would have meant a loss of the naval base. Therefore, Russia decided to annex Crimea (dependent variable). To test the hypothesis, this causal chain has to be verified empirically."

H1: In order to maintain its naval base in the Black Sea, Russia annexed Crimea.

Theory of international politics

- Neorealism by Kenneth Waltz: theoretical foundations

According to Kenneth Waltz, "states" are "the units" in the international

11 Cf. Guide to Methods for Students of Political Science (Van Evera 1997). 
system and their "interactions" form the "structure" of the system (Waltz 1979: 95). More precisely, that means that if the "distribution of capabilities" among the states changes, the structure of the system changes too (Waltz 1979: 97, 98). This structure in turn affects "the behavior of the states" (Schörnig 2010: 75; Waltz 1979: 92-93). The status of states in the international politics system depends on "all" of the states' "capabilities" (Waltz 1979: 131): on the "population," the size of a state's territory, and on economic and military power (ibid.). The anarchic ordering principle of the international politics system, which is characterized by an absence of "agents with system-wide authority" (ibid.: 88-89), implies that states ascribe their "security" the highest priority (ibid.: 126). All such states, which cannot help themselves, "will fail to prosper, will lie [...] open to dangers, will suffer" (ibid.: 118). Consequently, the states' primary goal is to survive - it is their "ground of action in a world where the security of states is not assured" (ibid.: 91-92). To ensure their survival, all states strive for an enlargement of their means (ibid.: 118, 125). Only a balance in the distribution of these means among the states guarantees a high degree of security (Schörnig 2010: 74). In doing so, the states apply both "economic means for military and political ends" and "military and political means for the achievement of economic interests" (Waltz 1979: 94).

\section{Operationalization and derivation of hypotheses}

The theory of structural realism ascribes the states' behaviour in the international system (dependent variable) to the structure of this system (independent variable). The distribution of power among the states affects the structure of the international system as well as the states' status in the system. Because of the anarchy in the international system, all states must care for their security on their own. The states' survival depends on the development of their means; on the other hand, this has an effect on the other states' behaviour. These means include military, as well as economic, strength.

By expanding its institutions, NATO and the EU, the West extended its military, economic and political means and this resulted in an imbalance 
of power..$^{12}$ In the "anarchic" system of international politics, Russia could have reacted to the expansion of the Western sphere of influence and Moscow could have tried to guarantee its own security. With regard to NATO's expansion, the state of research, mentioned in the introduction of this paper, refers to NATO's eastward expansion, to NATO's missile defence system (Eitelhuber 2015: 220) and a (possible) Ukrainian NATO membership. Russia ought to have reacted to NATO's expansion, in terms of its eastward enlargement and its missile defence system (independent variable), as thereby Moscow saw its security endangered (intervening variable). This would have motivated Russia to prevent a further increase of the West's military power, in the form of a NATO membership of the Ukraine (intervening variable), by annexing Crimea and (still) destabilizing eastern Ukraine (dependent variable). This causal chain must also be examined.

H2: By annexing Crimea and destabilizing eastern Ukraine, Russia reacted to NATO's expansion.

As regards the expansion of the European Union, the EU eastern enlargement, the European Neighborhood Policy and a further rapprochement, in the form of an association agreement between the EU and Ukraine, must be examined. ${ }^{13}$ Russia ought to have reacted to the EU's expansion, in terms of its eastward enlargement, to the European Neighborhood Policy and to the association agreement between the EU and Ukraine (independent variable), as because of this, Russia could have feared a weakening of its own economic and political sphere of influence (intervening variable). This must have motivated Russia to prevent a further increase of the West's power, in the form of a rapprochement between the Ukraine and the EU (intervening variable), by annexing Crimea and (still) destabilizing eastern Ukraine (dependent variable). This causal chain also needs to be analysed, in order to test the hypothesis.

H3: By annexing Crimea and destabilizing eastern Ukraine, Russia reacted to the expansion of the EU.

12 This will be assumed as a given fact; cf. bullet point two.

13 Cf. the introduction of this paper. 
Pseudostabilisierung durch Nationalismus und Krieg (Pseudo stabilization by nationalism and war) - Political-psychological theory by Stavros Mentzos: Theoretical foundations

Stavros Mentzos explains that "national distinction and [...] self-definition" are often created "through a degradation and humiliation of other nations" (Mentzos 1995: 71). It is the result of a "creation of an enemy stereotype and intolerance" regarding "all that is not [part] of the own nation" (ibid.: 76). The "process of an enemy differentiation" "promotes the integration and the identity" and strengthens "the own inner cohesion" (ibid.: 74). At this creation of an enemy stereotype, "own inner conflicts" are fended off "projectively" (ibid.: 74): "Clashes of interests" of a "nation" and resultant "tensions" are "projected externally" (ibid.). ${ }^{14}$ Such a "creation of a wefeeling" could be "imposed from top to bottom," or can be achieved by "externalization of the conflicts," therefore by "projecting to an actual existing or ad hoc created outer enemy" (ibid.: 75). If such a "pseudostabilization" is missing, this can cause an "insecurity and confusion within the self-definition," as the abrupt end of "the East-West conflict" illustrates, as well as the end of this particular "enemy stereotype" (ibid.: 73). The internal "integration" of a nation is thus acquired for a "stabilization of the conflict with an external enemy" (ibid.: 75). Or in other words: The "garbage [...] of the unsolved conflicts in reality gets disposed" "by externalization" (ibid. 1995: 76).

\section{Operationalization and derivation of the hypothesis}

The "self-definition" and an inner coherence of a nation (dependent variable) can be achieved by the "creation of an enemy image" (independent variable). By the end of the East-West conflict, Russia's "pseudo-stabilization," though, could have been lost. It seems possible that Putin wanted to blame the West for Russia's "growing economic and political contradictions" (Ostrovsky 2016:35), to cast the West as the villain in Russia's domestic policy crisis. Consequently Putin would distract from 
In the course of the obvious domestic crisis in Russia (in 2011 and 2012), the political leadership could have tried to externalize this crisis with the use of an enemy image, in order to whitewash the "internal tensions." Assuming that Russia's political leadership considered an externalization of domestic policy mischiefs necessary, they ought to have established an enemy stereotype of the West (independent variable), which should be fought against within the Ukraine (intervening variable). Therewith the Russian political leadership ought to have tried to reach an inner cohesion in Russia itself, in order to strengthen the legitimization of its regime domestically (intervening variable). As a result, Russia ought to have taken military action in Crimea and destabilized eastern Ukraine with the aid of troops (dependent variable).

H4: In order to strengthen its legitimization within Russia, the political leadership created an enemy image of the West, which must be fought against on Ukrainian territory.

\section{Analysis}

\section{Russia: maintaining military power - the Russian Black Sea fleet in Crimea}

The following section will analyse whether maintaining the Russian Black Sea fleet in Sevastopol and hence preserving its military power can possibly explain the Russian annexation of Crimea. It will be shown that Russia feared a termination of the contract on the maintenance of the Russian naval base on Ukrainian territory, because of Yanukovich's

15 Even with Russia's new military doctrine, a "connection between foreign and domestic policy risks" can be noticed (Klein 2015a: 4). 
overthrow, and as a consequence annexed Crimea. For that, first, the assumption must be examined as to whether the naval base in Crimea is actually central to Russia. The Russian fleet in the Black Sea has "the worst strategic location" of the "four Russian fleets,"16 and is also relevant for NATO and the "Euro-Atlantic security" (Alexandrova-Arbatova 2017: 17, 46). As early as 2003, Putin spoke about a "strategic interest" that the Black Sea region has for Russia: "The Black Sea gives Russia direct access to the world's major transport routes, including its economic routes" (Kremlin/ Putin 2003). Also, after the "referendum" on Crimea, Putin emphasized several times in his speeches the importance of the port city of Sevastopol to Russia; Putin characterized this city as "the birthplace of the Russian Black Sea fleet" and as "the main base of the Black Sea fleet" (Putin $2014 a)$. In this sense, the port city of Sevastopol is both of military and of economic relevance to Russia's power: "Sevastopol provides Russia icefree port access year round, and the means to project maritime and other military and commercial assets into the Balkans, the Mediterranean and the Middle East" (Cross 2017: 44). Admittedly Putin officially rationalized the annexation of Crimea by pointing to an interpretation of history (Putin $2014 \mathrm{~b})$, and yet the war between Russia and Georgia in 2008 visualized the "new [military] relevance" of the Black Sea to Russia, "with clashes between the two states at sea" (Seidler 2015: 104). The fact that the Russian naval base in Crimea is of particular (military) importance for Russia has been shown.

The relation between NATO and Ukraine was always stressed because of "the Russian naval base in Crimea" (Seidler 2015: 218-219). Due to this cooperation, Russia assessed its naval base on Ukrainian territory as being "endangered" (ibid.: 266). Especially because of the overthrow of the pro-Russian President Yanukovich, it seemed to be possible that a new, Western-orientated government would "probably" speak against a Russian naval base on Ukrainian territory (Mearsheimer 2014: 77; Treisman 2016: 48, 50). The treaty arranged in 2010 can be terminated by both sides, whereby Russia would have lost its "sole" naval base in the Black Sea (O'Hanlon/Petraeus 2016: 16). Having "control" over its Black Sea fleet and maintaining its naval base in Sevastopol seems to have been a crucial motive for annexing Crimea and the port city of Sevastopol, located therein (Cross 2017: 45). Thereby the conflict between Ukraine 
and Russia can be mainly explained as follows: "Maintaining access to the port city of Sevastopol and the security of the Black Sea fleet constitute the primary strategic source of the current conflict between Ukraine and Russia" (ibid.: 46). Since Russia has planned to further enlarge its Black Sea fleet, the strategic importance of the naval base has become clearer. So a further increase of " 80 new warships" is planned up to 2020 (ibid.). Although Stephen Sestanovich (2014: 172) sees no risk to the Russian naval base in Crimea, this analysis illustrates the opposite: By annexing Crimea and the city of Sevastopol, Russia seems to be preventing damage to its (military) power. ${ }^{17}$ It may be assumed that Russia has followed a policy of maintaining the status quo. Hypothesis $\mathrm{Hl}$ seems to be verified empirically.

\section{Distribution of capabilities in the system of international politics}

\section{Western military dominance: expansion of NATO}

Now it must be examined whether Russian behaviour can be explained by the West's military gain in power, in this case the expansion of NATO. The Russian "forces" are, "in all categories [,] inferior to NATO" (Eitelhuber 2015: 217). A military imbalance of power to the disadvantage of Russia may be taken for granted. ${ }^{18}$ NATO's expansion seems to be aimed at pursuing power and the ensuing "consequences" for "non-NATO members" did attract some attention (Müller 2015: 311-312).

Whether Russia did regard NATO's eastward expansion as a significant threat to its security must be analysed. For Putin, this expansion of NATO to Russia's borders - especially the enlargement of the "military infrastructure"

17 Besides, economic factors are likely to have mattered.

18 Cf. bullet point two. Between the US and the Soviet Union there was, however, a certain balance of power (Nye 2017: 12). 
- is not connected in any way "with the democratic choices of individual states" (Putin 2007). Putin even speaks about a "containment" of Russia by the West: "They are constantly trying to sweep us into a corner" (Putin 2014a; Putin 2014b). The eastward enlargement of NATO seems to be understood by Russia as a "serious provocation" (Putin 2007). Against these official statements by Putin - and thus against the thesis that Russia classes NATO as the "main threat" - reorganization of Russian forces is argued (Eitelhuber 2015: 218): Russia did not prefer a "large mobilization army" and the "Western military district" was not "strengthened," but Moscow enhanced its "special forces," which are "specialized in asymmetric warfare and fighting against terrorism" (ibid.). Yes, Russia did indeed reject NATO's eastward enlargement. The significance of this (bygone) expansion, however, has, in reference to the Russian behaviour in Ukraine since 2014, little relevance. If Moscow had rated its security at such risk because of NATO's eastward expansion, Russia would have adjusted its military power according to this threat. That seems not to be the case. Moreover, there are five years between NATO's latest enlargement and Russia's course of action in the Ukrainian crisis (NATO 2015). McFaul's conclusions illustrate this: "[F]or the previous several years" NATO did not expand towards the East (MCFaul 2014: 169; Dunay 2014: 59).

The following section will evaluate how endangered Russia judged its security in relation to NATO's missile defence system: Back in 2007, Putin had cautioned against an "arms race" initiated by the Western missile defence shield (Putin 2007). This missile defence shield poses a threat to Russian security, because it "neutralizes" entirely "the possible threat" of Moscow's "nuclear forces" (Putin 2007; Putin 2014b). As Russia's "secondstrike capability" is nullified by this system (Dickow et al. 2016:6), accordingly "the ultimate guarantee" of Russian "sovereignty" is in danger (Eitelhuber 2015: 220). As a consequence, NATO's missile defence system can be rated as the actual "main threat" to Russia (Eitelhuber 2015: 220). ${ }^{19}$ What's more, Russia feels "cheated" by NATO, because NATO had "lied" "many times" to Moscow. ${ }^{20}$

19 Although the termination of the "ABM treaty" by the "USA in 2002" increased the Russian "security concerns", the aim of the contract was to limit "missile defense systems" (Hacke 2014: 41).

20 In this regard, Putin refers to NATO's eastward enlargement and to the missile defense system. Harald Müller speaks about "vocal promises" that have been "broken" (Müller 2015: 310). Klaus von Beyme, on the other hand, doubts "such a commitment" (Beyme 2016: 56, 73). NATO also denies this: "No such pledge was made [...]" (NATO 2014). 
Because Russia rejects NATO's eastward enlargement, this could also be the case concerning membership of Ukraine in the Western defensive alliance, which Russia might have tried to prevent. In fact, Russia clearly rejected such an extension of NATO to Ukraine: "[W]e are against having a military alliance making itself at home right in our backyard or in our historic territory" (Putin 2014a). Ukraine's accession to NATO is generally regarded as "unacceptable" by the Russian elite (Mearsheimer 2014: 82). Above all, Putin feared the consequences of NATO's accession to Ukraine, in reference to Crimea and the port city of Sevastopol (Putin 2014a): "NATO's navy would be right there in this city of Russia's military glory, and this would create not an illusory but a perfectly real threat to the whole of southern Russia" (Putin 2014a). In addition, it is possible that Putin expected, with regard to the accession of Ukraine to NATO, the arrival of a NATO naval base in Crimea (Mearsheimer 2014: 77). Russia seemed to try to counter a further expansion of the Western military power. This had already been demonstrated by the Russian-Georgian war in 2008, in which it was Russia's intention to terminate "Georgia's progress towards NATO membership" (Kriendler 2014: 90; Zellner 2015: 92-93, 96). This can be transferred to Ukraine, because it is unlikely that a state "which is involved in military conflicts" can join NATO (Maćków 2015: 109). It could be alleged that Russia has adopted a strategy in which it pursues "nonintegration" into the West and a destabilization of "territories, which [...] [it] can directly or indirectly control" (Meister 2015: 4).21

In spite of all this, it is necessary to check whether the accession of Ukraine to NATO was (at all) probable. In the period from 2002 to 2008, Ukraine "tried four times to be included in the action plan for NATO membership," but this was prevented by the Germans and French (Göler 2015: 294; Umbach 2004: 309-310). Nevertheless, Michael McFaul notes: "For the last several years, neither the Ukrainian government nor NATO members wanted Kiev to join the alliance anytime soon" (McFaul 2014: 169; Sestanovich 2014: 172). And even before Yanukovich's reign, this was the case (McFaul 2014: 169; Dunay 2014: 59). An admittance of Ukraine into NATO is thus to be regarded as unlikely (Eitelhuber 2015: 315).22 On the basis of a NATO document from the year 2015, however, the NATO summit in Bucharest in

21 This is illustrated by the examples of "Syria, North Korea and Iran," where it is not certain "to what extent Russia" is interested "in a final solution of conflicts at all" (Klein 2015b: 46). 
2008 officially announced different resolutions:

\begin{abstract}
Allied leaders [...] agreed at Bucharest that Georgia and Ukraine, which were already engaged in intensified dialogues with NATO, will one day become members. In December 2008, Allied foreign ministers decided to enhance opportunities for assisting the two countries in efforts to meet membership requirements [...] (NATO 2015).
\end{abstract}

In 2008, the members of NATO formulated clearly their will "that these countries will become members of NATO" (NATO 2008). Although no specific timetable for the accession of Ukraine has been established, this may not be impossible. On the contrary, a bulk of NATO members wanted it. And also Ukraine's relations with NATO were further intensified (NATO 2008; NATO 2016b). Nevertheless, the "chaotic" manner of Russia points more to a "spontaneous reaction" to Yanukovich's fall and not to a long-planned strategy for the avoidance of NATO's expansion to Ukraine (Treisman 2016: 48).

It could be worked out that the Russian behaviour (probably) was not a reaction to "NATO's long-ago expansion" (McFaul 2014: 170). Indeed, there is no doubt that the eastward expansion of NATO was "a key and persistent irritant in NATO-Russia relations" and that the Russian leadership regarded it as a threat to its security (Kriendler 2014: 89; Beyme 2016: 56; Putin 2007). However, with regard to the Ukrainian crisis, NATO's eastward enlargement cannot be called the "taproot of the trouble." Nevertheless, Russia clearly saw (and sees) its security threatened by the NATO missile defence system. It is possible to prove Moscow's goal of preventing Ukrainian membership in NATO, and thereby a further gain of military power by the West. Still, Russian behaviour can only be partially justified by a preventive necessity of Russia in order to "prevent a possible further expansion of NATO" (Beyme 2016: 56), ,23 because an accession of Ukraine, although desired by NATO, did not occur in the foreseeable future. Overall, Russia seems to have targeted a "marginal position improvement and [...] symbolic-emotional satisfaction" (Müller 2015: 312). The Russian elite still felt "betrayed" by NATO (Putin 2014a). In particular, NATO's missile defence has further strengthened the "Russian feeling of

23 And yet Beyme speaks about an "escape [of Russia] into an expansion policy to prevent NATO from spreading to Crimea" (Beyme 2016: 90). 
encirclement" (Eitelhuber 2015: 222). Hypothesis H2 can be partially, but not clearly, verified by empiricism.

\section{Western economic and political dominance: expansion of the European Union}

This section analyses whether Russia reacted to the extension of the European Union by annexing Crimea and destabilizing eastern Ukraine. As NATO is militarily superior to Russia, the EU outclasses Russia in economic respects (Weidenfeld 2015: 205; Maćków 2015: 13-14): Through its enlargement, the EU has steadily expanded its economic power and its population. It should be stated that Russia has feared a weakening of its own economic and political power, because of the expansion of the EU.

However, the eastward enlargement of the EU seems not to have been criticized by Russia "for years" (Maćków 2015: 18; Zellner 2015: 93). However, in 2004, Putin said about the EU's eastward enlargement that it contributed to a rapprochement between the EU and Russia, "not only geographically but also economically and mentally" (Wipperfürth 2011: 41). And also at the security conference in 2007, Putin spoke of "spheres in which we cooperate" with regard to the EU, which he altogether appreciated as "very important and very interesting" (Putin 2007). Moscow's worry about a weakening of its own economic and political power, as a result of the eastward enlargement of the EU, cannot be demonstrated in this respect. In general, Russia seems to regard the European Union as "a politically acceptable, stabilizing and mediating force" (Ehrhart 2010: 121).

This could also be true about the European Neighbourhood Policy, which cannot be said to "prepare the countries in between [...] for membership in the Union," since there is "no incentive" for this (Maćków 2015: 108). However, with its European Neighbourhood Policy, the EU is striving to strengthen "civil society organizations" and thus a democratic civil society (European Commission 2013: 19-21). "Democratic development," and thus "constitutionality," "human rights" and "civil society," have top priority 
(ibid.). The spread of these norms can be regarded as a (political) threat to Putin's regime in Russia, because Putin is fighting precisely against these elements in his own country (Chodorkowskij 2016: 8). Moreover, it is in the interest of Moscow to keep Ukraine in its "political and cultural influence," which seems to be incompatible with "system reforms" or accession to the EU (Maćków 2015: 10).

The EU-Ukraine Association Agreement was, in fact, opposed by Russia as it threatened "the integration interests" of Russia's Eurasian Economic Union (Maćków 2015: 68). In this respect, "there would have been no dialogue" with Russia at all (Putin 2014b). The "massive pressure" of Russia against the agreement, which finally prevented the signing (Göler 2015: 300), demonstrates the Russian ambition to prevent a rapprochement between Ukraine and the EU. Russia's concern for its economy is clear: "[lt] is not about Ukraine's sovereign choice but about the consequences it will have on the Russian economy if it is signed" (Putin 2014c). While Putin emphasized cooperation with the EU at the EU-Russia meeting in January 2014, he simultaneously demanded,

to link the European and Eurasian integration processes. I am convinced that there are no contradictions between the two models [...] they could effectively complement each other and contribute to the growth of mutual trade turnover (Putin 2014c).

Nevertheless, it has been the EU that has delayed a "rapid integration" of Ukraine (into the EU) (Göler 2015: 294). The signing of the agreement has already been postponed by the European side as the "human rights situation" in Ukraine deteriorated (Göler 2015: 298). It was therefore not possible to expect an accession of Ukraine to the EU within the near future (Zellner 2015: 97). A further political and economic approach, on the other hand, took place, and Russia tried to prevent this. The Russian perspective on the EU has changed, especially in the last few years. Russia's own economic motives may be viewed as the (main) motive. Russia saw its own economic power increasingly endangered. Hypothesis H3 can, for the most part (though not clearly), be confirmed. 


\section{Russian crisis on the domestic front: creation of a foreign policy enemy stereotype}

Now it is necessary to investigate whether the Russian leadership, centred around Putin, tried to strengthen its legitimacy in its own country. This can be achieved by the externalization of the domestic political crisis. It is therefore necessary to prove if an enemy image was created - which Russia claims to fight (militarily) in Ukraine. The fact that it was necessary for the political leadership of Russia to divert internal political grievances through an externalization of an enemy stereotype can be substantiated. Putin has "feared" protests in Russia, particularly against the background of the "Orange Revolution in 2004" in Ukraine and the "Arab Spring" (McFaul 2014: 170).24 The Ukrainian Maidan was also "highly dangerous" for Putin's regime (Quiring 2014: 16).25 That the domestic political crisis was viewed by the Russian leadership as a serious threat has been proven.

Michael McFaul considers this domestic "attack" on "Putin and his regime" to be decisive for the change in Russian foreign policy (McFaul 2014: 169). Consequently, Putin seemed to have established an enemy stereotype of the West, especially with regard to the United States, in order to mobilize his "electoral base" in Russia (Mc Faul 2014: 170; Schröder 2014: 9). In fact, Putin and his foreign minister, Sergey Lavrov, at the end of 2014, accused the West of refusing a "dialogue," and both blamed the West for being co-responsible for the "coup" in Ukraine (Putin 2014b; Lawrow 2014). The Western sanctions against Russia Putin labels as a "containment," which would have taken place even without the events in Ukraine (Putin 2014b). Moreover, "some Western politicians" "threaten" Russia "not only with sanctions" but also with "the prospect of increasingly serious problems on the domestic front" (Putin 2014a). In his speech, Putin further asks: "[A] re they hoping to put us in a worsening social and economic situation so as to provoke public discontent?" (Putin 2014a). This seems to reflect the fact that Putin blames the West for the domestic political problems of Russia. Putin also criticizes the West: "Our Western partners, led by the

24 In the course of the so-called "color revolutions," Russia preferred "stability and the status quo" in the states - in contrast to the West (Cross 2017: 39). 
United States of America, prefer not to be guided by international law in their practical policies, but by the rule of the gun" (Putin 2014a). The construction of an enemy image of the West becomes particularly clear in this speech by Putin:

\begin{abstract}
And all this while Russia strived to engage in dialogue with our colleagues in the West. [...] [T]here is a limit to everything. [...] [T] hey were fully aware that there are millions of Russians living in Ukraine and in Crimea. They must have really lacked political instinct [...] not to foresee all the consequences of their actions. Russia found itself in a position it could not retreat from (Putin 2014a).
\end{abstract}

Thus, Putin accuses the Western states of influencing Ukraine: "[W]ith Ukraine, our Western partners have crossed the line, playing the bear and acting irresponsibly" (Putin 2014a). Accordingly, the West would support a "well-equipped army of militants" in Ukraine, and such actions would be "against Ukraine and Russia and against Eurasian integration" (Putin 2014a).

It is now necessary to prove whether Putin achieved an internal cohesion in Russia through this externalization of the domestic political crisis in Russia. In fact, the literature points out that Putin has regained "legitimacy among the [Russian] population" by annexing Crimea (Meister 2015: 2; Schröder 2014: 9). By defying the West in Ukraine, Putin's "support" seems to have risen in Russia (Cross 2017: 41). This is also confirmed by Putin's approval ratings. The ratings were "at least under 50 percent" at the beginning of 2012 , and actually since the annexation of Crimea they seem to have "increased to 80 per cent" (Maćków 2015: 66). Other sources point out that Putin's approval ratings have already stabilized since the (domestic) crisis in Russia at the end of 2011 and early 2012, and reached almost 70 percent in December 2012 (BpB 2014). However, by January 2014, the approval had fallen to about 60 percent, before it increased continuously from February 2014 onwards to more than 75 percent (ibid.).

Thus, it can be assumed that the Putin regime had a stabilizing effect on the domestic front, because of the annexation of Crimea and the destabilization of eastern Ukraine. "Own internal cohesion" in Russia seems 
to have been achieved, at least for the time being, and the formation of the enemy stereotype can be regarded as successful. While "38 percent" of Russians had a "negative" picture of the US in 2013, it was "71 percent" in 2014 (Sputnik 2014). It could be shown that Russia claims to fight the Western enemy in Ukraine, which is blamed by the Russian leadership for the bad domestic situation in Russia. Russia seems to combat militarily the enemy image of the West in Ukraine, both in the east of the country and in Crimea. Overall, Hypothesis $\mathrm{H} 4$ was confirmed.

\section{Conclusions}

The analysis shows that with the Russian naval base in Crimea, at least the annexation of this - and the port city of Sevastopol - by Russia can be explained. The analysis of Russia maintaining its military strength, at the analytical level of the state, was particularly revealing.

On the other hand, the expansion of NATO and the EU appears to (partly) explain Russian behaviour. In both cases, the Russian course of action was not clearly explained by the eastward enlargement of both Western institutions. In addition, Ukrainian membership of NATO, in the near future, may be considered unlikely. With regard to the EU, it has only been in the last few years that Russia has worried more about its own economy and about its Eurasian Union. Accordingly, Russia tried to prevent further economic and political rapprochement between Ukraine and the EU. Overall, the results of the analysis at the level of the system were less clear.

The construction of an enemy image of the West could be demonstrated. This, in fact, seems to serve to project domestic mischief to the outside. For the time being, this attempt by the Russian leadership may be described as successful. The hypothesis can be confirmed quite clearly.

Further steps by Russia, in the sense of an extension of its territory, cannot be ruled out, but they seem to be unlikely. With its aggressive behaviour, Russia has first of all certainly achieved one thing: The West has also 
( experienced an increased "internal cohesion" (Maćków 2015: 98). The European states, although faced with internal political challenges, are increasing their military spending - and NATO is experiencing a "new right to exist" (Lukjanow 2016). 


\section{Bibliography}

Alexandrova-Arbatova, N., 2017. Security relations in the Black Sea region: Russia and the West after the Ukrainian crisis. In: Manoli, P., ed. Aftermath of the Ukrainian Crisis. London/New York: Routledge. pp.11-22.

Beddoes, Z. M., 2016. Planet Trump: The world in 2017. The Economist, 9 November, pp. 13-14.

Beyme, K., 2016. Die Russland-Kontroverse. Eine Analyse des ideologischen Konflikts zwischen Russ/and-Verstehern und Russland-Kritikern. Wiesbaden: Springer VS.

Bos, E., 2010. Das politische System der Ukraine. In: Ismayr, W., ed. Die politischen Systeme Osteuropas. Wiesbaden: Springer VS. pp. 527-582.

BpB, 2014. Umfrage. Putins Popularitätswerte. Bundeszentrale für politische Bildung, [online]. Available at: http://www.bpb.de/internationales/ europa/russland/181699/umfrage-putins-popularitaetswerte (Accessed 1 March 2017).

Chodorkowskij, M., 2016. Putin erhöht den Einsatz bis ins Endlose. FAZ, Nr. 249: 8.

Cross, S., 2017. NATO-Russia security challenges in the aftermath of Ukraine conflict. Managing Black Sea security and beyond. In: Manoli, P. ed. Aftermath of the Ukrainian crisis. London/New York: Routledge. pp. 33-60.

Dickow, M., Paul, M., Meier, O. and Kubiak, K., 2016. Deutschland und die Nato-Raketenabwehr. Zwischen Anpassungsbedarf und Beharrungsvermögen. Stiftung Wissenschaft und Politik -SWPDeutsches Institut für Internationale Politik und Sicherheit, [working paper]. Available at: http://www.ssoar.info/ssoar/handle/ document/46602 (Accessed 23 February 2017).

Dunay, P., 2014. NATO enlargement. Close to the end. In: Herd, G. P., Kriendler, J. eds. Understanding NATO in the 21 st Century. Alliance 
strategies, security and global governance. New York: Routledge. pp. 50-66.

Ehlers, K., 2014. Zankapfel Ukraine. Europäische versus Eurasische Union. Blätter für deutsche und internationale Politik, 2/2014: 25-28.

Ehrhart, H., 2010. Die EU im Einsatz: Friedensmacht oder Wolf im Schafspelz. Zeitschrift für Außen- und Sicherheitspolitik, 4(1): 109-127.

Ehrhart, H., 2014. Russlands unkonventioneller Krieg in der Ukraine. Zum Wandel kollektiver Gewalt. APUZ, 64: 26-31.

Eitelhuber, N., 2015. Russland im 21. Jahrhundert. Reif für eine multipolare Welt? Eine Analyse der strategischen Kultur Russlands und das daraus abgeleitete Erfordernis einer konfliktsensiblen Außen- und Sicherheitspolitik gegenüber Russland. Frankfurt a. M.: Peter Lang.

Engelberg, A., 2016. Im Fadenkreuz der Geopolitik. Die Ukraine und der neue Kalte Krieg. Blätter für deutsche und internationale Politik, 11: 61-67.

European Commission. Europäisches Nachbarschafts- und Partnerschaftsinstrument. Länderstrategiepapier 2007-2013 - Ukraine 2013. [pdf]. Available at: https://ec.europa.eu/europeaid/sites/ devco/files/csp-ukraine-2007-2013_de.pdf (Accessed 7 March 2017).

Giegerich, B., 2012. Die NATO. Wiesbaden: Springer VS.

Göler, D., 2015. Wenn normative Macht zur geostrategischen Herausforderung wird. Überlegungen zur aktuellen Ukraine-Krise. ZfP, 62(3): 289-305.

Hacke, C., 2014. Der Westen und die Ukraine-Krise. Plädoyer für Realismus. ApuZ, 64: 40-47.

Hösle, V., 2015. Macht und Expansion. Warum das heutige Russland gefährlicher ist als die Sowjetunion. Blätter für deutsche und internationale Politik, 6: 101-110.

Klein, M., 2015a. Russlands neve Militärdoktrin. Nato, USA und farbige Revolutionen im Fokus. SWP-Aktuell 12, February [pdf]. Available at: https://www.swp-berlin.org/fileadmin/contents/products/ aktuell/2015A12_kle.pdf (Accessed 27 January 2017). 
Klein, M., 2015b. Russland. Wohin steuert die ehemalige Weltmacht?. Bundeszentrale für politische Bildung, [online]. Available at: http:// www.bpb.de/izpb/209652/internationale-sicherheitspolitik?(Accessed 27 January 2017).

Krell, G. ed., 2009. Weltbilder und Weltordnungen. Einführung in die Theorien der internationalen Beziehungen. Baden-Baden: Nomos.

Kremlin, 2010. Presidents of Russia and Ukraine signed an agreement extending the presence of Russia's Black Sea Fleet on Ukrainian territory. President of Russia, 21 April [online]. Available at: http:// en.kremlin.ru/events/president/news/48812 (Accessed 11 February 2017).

Kremlin/Putin, W., 2003. The Black Sea gives Russia direct access to the world's major transport routes, including its economic routes, President Vladimir Putin said at a meeting on military and diplomatic matters at the Yeisk branch of the Gagarin Air Force Academy. President of Russia, 17 September [online]. Available at: http:// en.kremlin.ru/events/president/news/29375 (Accessed 11 February 2017).

Kriendler, J., 2014. NATO-Russia relations. Reset is not a four-letter word. In: Herd, G. P., Kriendler, J. eds. Understanding NATO in the 21 st century. Alliance strategies, security and global governance. New York: Routledge. pp. 85-101.

Lawrow, S., 2014. Antworten auf Fragen der Agentur Interfax. Außenministerium der Russichen Föderation, 21 April [online]. Available at: http://www.mid.ru/de/press_service/minister_ speeches/-/asset_publisher/7OVQR5KJWVmR/content/id/871570 (Accessed 28 February 2017).

Lippert, B., 2014. Die Ukraine-Krise und kritische Fragen an die EUErweiterungspolitik. Stiftung Wissenschaft und Politik-SWP-Deutsches Institut für Internationale Politik und Sicherheit, [working paper]. Available at: http://nbn-resolving.de/urn:nbn:de:01 68-ssoar-384835 (Accessed 21 February 2017).

Lukjanow, F., 2016. Analyse: Logik der Konfrontation - das interne Motiv. Bundeszentrale für politische Bildung, [online]. Available at: http:// 
www.bpb.de/internationales/europa/russland/231537/analyselogik-der-konfrontation-das-interne-motiv (Accessed 18 March 2017).

Maćków, J., 2015. Die Ukraine-Krise ist eine Krise Europas. Berlin: edition. fotoTapeta.

Mazarr, M. J., 2017. The once and future order. What comes after hegemony. Foreign Affairs, 96(1): 25-32.

McFaul, M., 2014. Faulty powers. Who started the Ukraine crisis? Foreign Affairs, 93(6): 67-171.

Mearsheimer, J. J., 2014. Why the Ukraine crisis is the West's fault. The liberal delusions that provoked Putin. Foreign Affairs, 93(5): 77-89.

Meister, S., 2015. Fünf Illusionen über das System Putin. Bundesakademie für Sicherheitspolitik, Arbeitspapier Sicherheitspolitik, Nr 6, [pdf]. Available at: https://dgap.org/de/article/getFullPDF/26967 (Accessed 3 February 2017).

Mentzos, S., 1995.Pseudostabilisierung deslchdurchNationalismusund Krieg. In: Rohde-Dachser, C. ed. Über Liebe und Krieg. Psychoanalytische Zeitdiagnosen. Göttingen-Zürich: Vandenhoeck\&Ruprecht. pp. 66-84.

Menzel, U., 2016. Welt am Kipppunkt. Die neve Unregierbarkeit und der Vormarsch der Anarchie. Blätter für deutsche und internationale Politik, 1/2016: 5-45.

Morgenthau, H. J., 1963. Macht und Frieden. Grundlegung einer Theorie der internationalen Politik. Gütersloh.

Müller, H., 2015. Konturen einer neven europäischen Friedensordnung. ZfP, 62(3): 306-322.

NATO, 2008. Bucharest Summit Declaration. North Atlantic Treaty Organization, last updated: 8 May 2014 [press release]. Available at: $\quad$ http://www.nato.int/cps/en/natohq/official_texts_8443. htm? mode=pressrelease (Accessed 26 February 2017).

NATO, 2014. Russia's accusations - setting the record straight. North Atlantic Treaty Organization, last updated: 12 May 2014 [online]. 
Available at: http://www.nato.int/cps/en/natohq/topics_109141. htm? selectedLocale=en (Accessed 26 February 2017).

NATO, 2015. Enlargement. North Atlantic Treaty Organization, last updated: 16 June 2017 [online]. Available at: http://www.nato.int/cps/en/ natohq/topics_49212.htm? selectedLocale=en\# (Accessed 26 February 2017).

NATO, 2016a. Ballistic missile defence. North Atlantic Treaty Organization, last updated: 25 July 2016 [online]. Available at: http://www. nato.int/cps/en/natohq/topics_49635.htm? selectedLocale=en (Accessed 26 February 2017).

NATO, 2016b. Relations with Ukraine. North Atlantic Treaty Organization. last updated: 11 July 2017 [online]. Available at: http://www. nato.int/cps/en/natohq/topics_37750.htm?selectedLocale=en (Accessed 26 February 2017).

Niblett, R., 2017. Liberalism in retreat. The demise of a dream. Foreign Affairs, 96(1): 17-24.

Nye, J. S. Jr., 2017. Will the liberal order survive? The history of an idea. Foreign Affairs, 96(1): 10-16.

O'Hanlon, M., Petraeus, D., 2016. America's awesome military. And how to make it even better. Foreign Affairs, 95(5): 10-17.

Ostrovsky, A., 2016. Lenin`s revenge. The Economist, 9 November, p.35.

Portnov, A., 2014. Postsowjetische Hybridität und Eurorevolution in der Ukraine. APUZ, 64: 3-8.

Putin, W., 2007. Rede auf der Münchner Sicherheitskonferenz. President of Russia, 10 February [online]. Available at: http://en.kremlin.ru/ events/president/transcripts/24034 (Accessed 8 February 2017).

Putin, W., 2014a. Address by President of the Russian Federation. President of Russia, 18 March [online]. Available at: http://en.kremlin.ru/ events/president/news/20603 (Accessed 8 February 2017).

Putin, W., 2014b. Die Krim hat eine sakrale Bedeutung für Russland. Rede des russischen Präsidenten Wladimir Putin zur Lage der Nation. Blätter für deutsche und internationale Politik, 4 December [online]. 
Available at: https://www.blaetter.de/archiv/jahrgaenge/ dokumente/\%C2\%BBdie-krim-hat-eine-sakrale-bedeutung-fuerrussland\%C2\%AB (Accessed 7 February 2017).

Putin, W., 2014c. Russia-EU Summit. President of Russia, [online]. Available at: http://en.kremlin.ru/events/president/news/page/189 (Accessed 25 March 2017).

Quiring, M., 2014. Putin's poker. Blätter für deutsche und internationale Politik, 8/2014: 13-16.

Schörnig, N., 2010. Neorealismus. In: Schieder, S., Spindler, M. eds. Theorien der internationalen Beziehungen. Opladen: Budrich. pp. 65-96.

Schröder, H., 2012. Russland unter den Präsidenten Putin und Medwedew 1999-2012. Bundeszentrale für politische Bildung, [online]. Available at: http://www.bpb.de/internationales/europa/ russland/? blickinsbuch (Accessed 11 January 2017).

Schröder, H., 2014. Volk und Macht. Die schwache Verankerung des Systems Putin in der Gesellschaft. Russland Analysen, Nr. 281 [pdf]. Available at: http://www.laender-analysen.de/russland/pdf/ RusslandAnalysen281.pdf (Accessed 11 January 2017).

Seidler, F., 2015. Maritime Herausforderungen der NATO. Strategische Auswirkungen und die Effektivität des Handelns. Frankfurt a. M.: Peter Lang.

Sestanovich, S., 2014. How the west has won. Foreign Affairs, 93(6): 171175.

Sputniknews, 2014. Umfrage in Russland. USA und Ukraine gelten als Hauptfeinde. SputnikNews, 6 June [online]. Available at: https:// de.sputniknews.com/zeitungen/20140606268697056-Umfrage-inRussland-USA-und-Ukraine-gelten-als-Hauptfeinde-/ (Accessed 1 March 2017).

Treisman, D., 2016. Why Putin took Crimea. The gambler in the Kremlin. Foreign Affairs, 95(3): 47-57.

Umbach, F., 2004. Die zweite Runde der NATO-Osterweiterung aus der Sicht Russlands. In: Pradetto, A. ed. Die zweite Runde der NATOOsterweiterung. Zwischen postbipolarem Institutionalismus und 
offensivem Realismus. Frankfurt a. Main: Peter Lang.

Van Evera, S., 1997. Guide to methods for students of political science. Ithaka: Cornell University Press.

Waltz, K., 1979. Theory of international politics. New York.

Weidenfeld, W., 2015. Die Europäische Union. Paderborn: Wilhelm Fink.

Wessels, W., 2009. Das politische System der Europäischen Union. In: Wolfgang, I. ed. Die politischen Systeme Westeuropas. Wiesbaden: Springer VS. pp. 957-992.

Wipperfürth, C., 2011 . Russlands Außenpolitik. Wiesbaden: Springer VS.

Zellner, W., 2015. Entfeindung durch Dialog. Vom heißen Krieg in der Ukraine zum Frieden in Europa. Blätter für deutsche und internationale Politik, 8/2015: 89-98.

Maximilian Klotz (Maximilian.Klotz@stud.uni-regensburg.de) is a BA student of political science, as his main subject, as well as of history and art history, at the University of Regensburg. His main focus is on the development of Western democracies and the new power relations between the USA, Russia and China. He recently wrote scientific papers on the democratic quality of Russia under Putin and analysed the influence potential of the most important scientific advisory body of the Federal Republic (Sachverständigenrat zur Begutachtung der gesamtwirtschaftlichen Entwicklung - Council of Economic Experts). He currently works as a Student Assistant at the Chair for Modern and Contemporary History of Professor Baver. 